\title{
IMPROVING LISTENING SKILL OF REPORT TEXT THROUGH LEARNING CELL AND PINACOY
}

\author{
Kuswahyuningsih \\ kuswahyuningsih@yahoo.co.id \\ MAN Sukoharjo
}

\begin{abstract}
A lot of students encounter obstacles in mastering listening skill of report text. The goals of study are to describe the influence of applying learning cell and utilizing of Pinacoy toward listening skill especially in report text of Second Year Students of Social Program in MAN Sukoharjo. The study is also to describe the students's listening ability of applying Learning cell and the utilizing of Pinacoy .The technique is utilized to collect the data in this study is classroom action research. The data validity of this study uses interview, observation, and test. The results of study are that there are influence of applying learning cell and the utilizing of Pinacoy toward listening skill especially in report text and the average of students' scores can reach KKM (passing grade standard) after the researcher applied learning cell and utilized Pinacoy toward listening skill.
\end{abstract}

Keywords: listening, report text, learning cell, Pinacoy

\section{INTRODUCTION}

The students of grade XI encounters obstacles in mastering report text listening skill. These matters can be seen from daily test of XI grade social 2 which is more than $50 \%$ of unsuccessful students in attaining KKM (passing grade standard). The determined KKM is 60. Among 27 students in the XI grade social 2 in MAN Sukoharjo, there are 24 students who participate in daily test, it is found that 11 students get 50 . The lowest score is 30 and highest one is 70 , with average score 52.92 .

Students have problem in receptive skill for instance they are not familiar with the sound of the word. On the other hand, students' failure in listening skill in report text is not separated by the teacher's role. First, the teacher does not use the appropriate learning media effectively yet. Second, the teacher does not utilize suitable approach well in learning process. One factor which causes teacher does not utilize appropriate learning media effectively is because the school does not provide the learning facilities yet.
Munadi (2008, 23) stated that learning media holds strategic role in conducting an effective learning. Smaldino et. al. $(2008,25)$ stated that media is a tool of communication. It purposed to attain learning material easier. The educator must be able to choose and classify learning media that will be used to convey the competences in each and subject. Barkley et. Al. (2005) stated that Learning cell is based on collaborative learning technique. Collaborative learning technique emphasizes the importance of promotive interaction and individual accountability. It is structured learning activity that addresses major concerns related to improving student learning.

Based on the previous explanation, it can be concluded that the key of learning success is teacher's ability in choosing learning media which is appropriated with characteristic of each material. Therefore, teacher as a researcher intends to carry out a classroom action research by using audio-visual learning media to improve listening skill. In improving listening skill, learning approach which will be 
applied is learning cell.The problem statements of this research are: (1) how is the influence of applying learning cell and utilizing Pinacoy toward learners' listening skill of report text of XI Grade Social 2 Students of MAN Sukoharjo in 2013/2014 Academic Year ?; (2) how are the learners' listening skills of report text of XI Social 2 Grade Students of MAN Sukoharjo in 2013/2014 Academic Year after applying learning cell and utilizing Pinacoy?

The objectives of this research are: (1) to describe the effect learner's listening skill of report text toward applying learning cell and utilizing Pinacoy toward XI Grade Social 2 Students of MAN Sukoharjo in 2013/2014 Academic Year in listening skill of report text?; (2) to describe the learners' listening skill of report text of XI Grade Social 2 Students of MAN Sukoharjo in 2013/2014 Academic Year after the applying learning cell and utilizing Pinacoy.

\section{THEORETICAL REVIEW}

\section{Listening Skill}

According to national of education ministry regulation no. 75 in 2009 about Passing Grade Competency Standard, listening skill is students' skill in understanding an oral text which is either interpersonal or transactional, both formally and informally in the form of narrative, recount, procedure, descriptive, news item, report, analytical exposition, hortatory exposition, spoof, explanation, discussion, and review in daily context.

On the writer's point of view, the process of listening is information acceptance of sound which followed by the phase of storing information in human brain, and the process of internalization understanding that they attain afterward. The listening process actually cannot be separated from hearing sensory organ and brain activity such as memorizing. Therefore, successful listening process is not related with the listeners' cleverness, but how they focus on catching information. In English learning, especially listening skill, teacher's role is to create process and learning environment in order to optimize learners' hearing sensory organ to be effective and focus on receiving information.

Newton et. al. (2009, 158) stated that there are many methods to teach listening skill for learners which namely listening and Speaking. Listening technique involve meaning focused activity. These activities involved listening to interesting thing and activities with clear communication outcome. It means that, listening skill should be taught in focus, attractive, and particular activities.

\section{Applying Learning Cell}

Barkley $(2005,140)$ stated that learning cell is the technique of teaching when student individually develops question about assignment or other learning activity and then work with a partner, alternating asking and answering each other's question. The purpose CoLT is to engage students actively in thinking about content, to encourage students to generate thought-provoking questions and to teach students how to check their understanding. Creating for question about an assignment requires students to think about the content in a way that is different from simply taking note on it. It provides an opportunity for students to think analytically, to elaborate as they put material into their own word, and to begin use the language of the discipline. Responding to the question of peer provides a platform for discussion based on students level of understanding. Exchanging question and answer with a peer can motivate students and challenge them to pursue deeper level of thought. The technique motivates students interpersonal skill such as giving feedback in non threatening ways, maintaining focus and developing 
and sustaining mutual tasks. Students learn to question, explain, admit confusion, and reveal mis conception something that they are more likely to do with a peer than with instructor. Finally, an effective partner can act as role model for useful learning strategies. The procedure is as follows:

1. Ask students to individually develop a list of questions and answers dealing with the major points in listening assignment

2. Form student pairs, or simply ask students to partners to alternate asking and answering each other question

3. Explain the process by which you want partners to alternate asking and answering each other's question

4. Student A begins by asking the first question, and student B answers the question. Stuedent A offers corrections and additional information until a satisfactory answer is achieved

5. Student B asks the next question and student $\mathrm{A}$ answers and the process repeat until all questions have been and answered.

\section{Utilizing Pinacoy}

Smaldino et. al. (2011, 7) states that media is a channel of communication. It is a tool or method and technique used to make the communication and interaction between the teacher and the student in teaching learning process to be more effective. Media is device of expressing massage and information. It can be concluded that the media relates to technique, method in teaching and learning process.

Sudjana (2003, 23) argued that there are many criteria in selecting media. It is as follows:

1. Media should be on instructional objectives that have been endorsed in curriculum. It consist of application, analysis, synthesis in teaching media;

2. Media should support the content of instructional material. It shows reality, clear that make the learner understand the lesson easily;

3. Media is easy to seek. It is practically simple in application.

There are some major principles in using media. First, the media and the method should complete each other, they cannot stand by themselves. Media supports the application of one method, and the method needs a media to convey the method. Second, media is more appropriate to be used in conveying a unit of lesson. A lesson may be running well when a particular media is applied, while the same media might not be used to teach other lesson unit.

Media for teaching is a media that can be used to help the students in their study, in order to make the teaching learning process more effective and efficient. By using media, the material is more interesting concrete and easier to understand.

One of the roles of media is to attract the student's attention and to deliver the information. There are various kinds of media, but visual are the appropriate media for young learner. According to Wright (1989) states that, in making decision to use the media, the teacher need to ask three out five basic questions, that is: (1) Is it easy for us to prepare?; (2) Is it easy to organize in the classroom?; (3) Is it interesting to the students? The three criteria can be applied by any teacher including teachers for beginners.

There are various kinds of visual which can be effectively used by the EFL teacher in their classroom. Teachers of young learner have to use some visual in their teaching activities to facilitate their teaching. In general, some of the visuals are still pictures, reality, drawing or teacher drawing, chart, poster, cartoons, and real objects.

Some schools have already been equipped with modern media, such as radio and video tape materials. In this case, songs, stories, poems and dialogue are available in teaching foreign 
language. Many kinds of supplementary material can be placed in media. EFL teacher use media in their English class learning, so in SMP/SMA students will be learning the foreign language through the concept example of things found in the real world, and the advantages of using media instructional media for EFL classes: (1) It attracts student's interest; (2) It gives more opportunity for the students to use the language; (3) It attracts student's attention; and (4) It adds a pleasure variety to English learning.

In this research, the word 'Pinacoy' stands for Pinnacle, Cool Edit Pro and You Tube. Sudjana et. al. (2008, 3) stated that learning media means a center, delivers, or intermediary. The meaning of learning media is all of the things are able to deliver the message of the structured source so that it created the concussive learning environment where the learners learn efficient and effectively. Munadi $(2008,9)$ states that media in the learning context is the teacher's language. Verbal language is all kinds of communication using one word or more while non-verbal language is all of messages.

Audio visual media is learning media that consists of voice of movie, video and television. In these recent research, there are the following things to be observed into the application of video during the learning process as follow: (1) The video must be chosen as the purpose of the learning; (2) The teacher has to recognize the available video's program and take the advantage for the subject; (3) The video is needed to play frequently to notice the certain aspects; (4) The theme of the video's contents is displayed in order that the students do not view that the playing video just as entertain media; and (5) The teacher drafts the learners' understanding toward the appropriate video displayed.

\section{Pinnacle}

Alim et. al. $(2011,3)$ explained that pinnacle is the most popular software video editing in the professionals or newbie (beginner) an easy process into application and many effects of the application that often uses so that makes this software enough to be best seller in market and the result is not far from the others professional software. Alim et. al. (2011, 15) claimed that pinnacle is simpler and user friendly than the user using this product/program more complex as premier or after effect. Moreover, pinnacle needn't too high speck computer so we can edit a video at home or our laptop. Further explanation that pinnacle makes something easier like auto detection to hardware that you input into pc or your laptop, if your laptop have webcam, it can process the video production.

In this case, the researcher argues that application of pinnacle program needs to edit the video and audio from you tube file had been taken as teaching material in this classroom action research because pinnacle gives an acceptance of video editing and audio.

\section{Cool Edit Pro}

Anderton (2002, 92) said that Cool Edit started life as inexpensive, capable digital audio editing program. It means that Cool edit pro is a program application in recording and file editing. Furthermore, Husein (2004, 4) stated that cool edit pro is software that used to files editing which existences into mp3, wav, cda and supports into sound format.These are the following steps to use Cool Edit Pro: (1) open cool edit program; (2) choose 'file ope'n; (3) click 'record' to start recording; (4) enter the result of recording into file, and (5) click edit for editing the result of recording.

\section{YouTube}

Darma et. al. (2009, 390) defined You Tube as one of the most popular website video sharing where the user can upload, share with other users 
along with watching the video. Commonly the video likes quotation of movie, music clip video, and many of independence video approximately one up to ten minutes in displays.

\section{Previous Study}

Several researchers have conducted the study of english teaching which applies technique and media. They are Song (2011) and Yunus et. al. (2012). Both of the researchers deliver the use internet and computer oriented in education. Song's study (2011) is entitled $A$ Web Survey Program Based on Computer Technology and Its Application to Evaluation Model about Youth Self-Organization in China. The study forecasts the developmental trend of adolencents by analyzing their current situation in China and build the evoluation model for youth selforganization. The web survey program uses the IIS web server + ASP.NET service + SQL server database. Survey .aspx could be generated in the server dynamically, so the web survey program can achieved by computer. Yunus et. al (2012) investigated the pre-service teachers' perceptions of a writing software called "paragraph punch" as a tool for assisting beginner writers. The purpose of the study is to investigate the pre-service teacher's perception of a writing software called Paragraph Punch for developing and organizing paragraphs in essay writing. The research also provides an overview of the development of computer-assisted language learning (CALL) over the years, and the background and features of Paragraph Punch. Data of the study have been gathered from third-year TESL students in state university of Malaysia using questionnaire survey to elicit their view on the uses of Paragraph Punch as a potential writing tool. The writer realized that some previous study have got their different stresses in their research. The recent study investigates the using of learning cell and utilizing Pinacoy as a media to increase student's listening skill.
Departs from the previous differences, the position of current study is to extend some previous researches that have been conducted.

\section{RESEARCH FRAMEWORK}

Based on the study above, the researcher can deliver framework that underlies this following research as seen in Diagram.

\section{RESEARCH METHOD}

This research is conducted to eleventh grade students in the class of social 2 MAN Sukoharjo. The research period until the report completion is in the first semester of academic year $2013 / 2014$, it began on July to September 2013. This research subject is listening skill of 27 students in the eleventh grade class of social 2 MAN Sukoharjo in academic year 2013/2014. Meanwhile the collecting data techniques are document analysis, observation, interview, and test. Data validity in this research applies triangulation method, which uses more than one technique of collecting data and more than one observer during treatments.

In addition, the data analysis procedure in this research is as follows:

1. Observation

The technique which is used to analyze data collected by class observation is qualitative descriptive analysis technique. This technique consists of activities to disclose weakness and strength of both teacher and learners' performance in teaching learning process based on latticework of observation by considering research indicator.

2. Interview

Data obtained from interview will be analyzed with qualitative descriptive analysis technique, by comparing learners' statement during the interview with class observation results. Interview is noted and transcribed. 
3. Test

Data obtained from test will be analyzed quantitatively by calculating mean, median, and mode from the learners' test scores both in the first and second cycles. Further, reflecting. Further, the primary activity of applying learning cell is started with develop a list of question and answer dealing with the major points raised in listening. The next step, teacher present model of text. It similar to

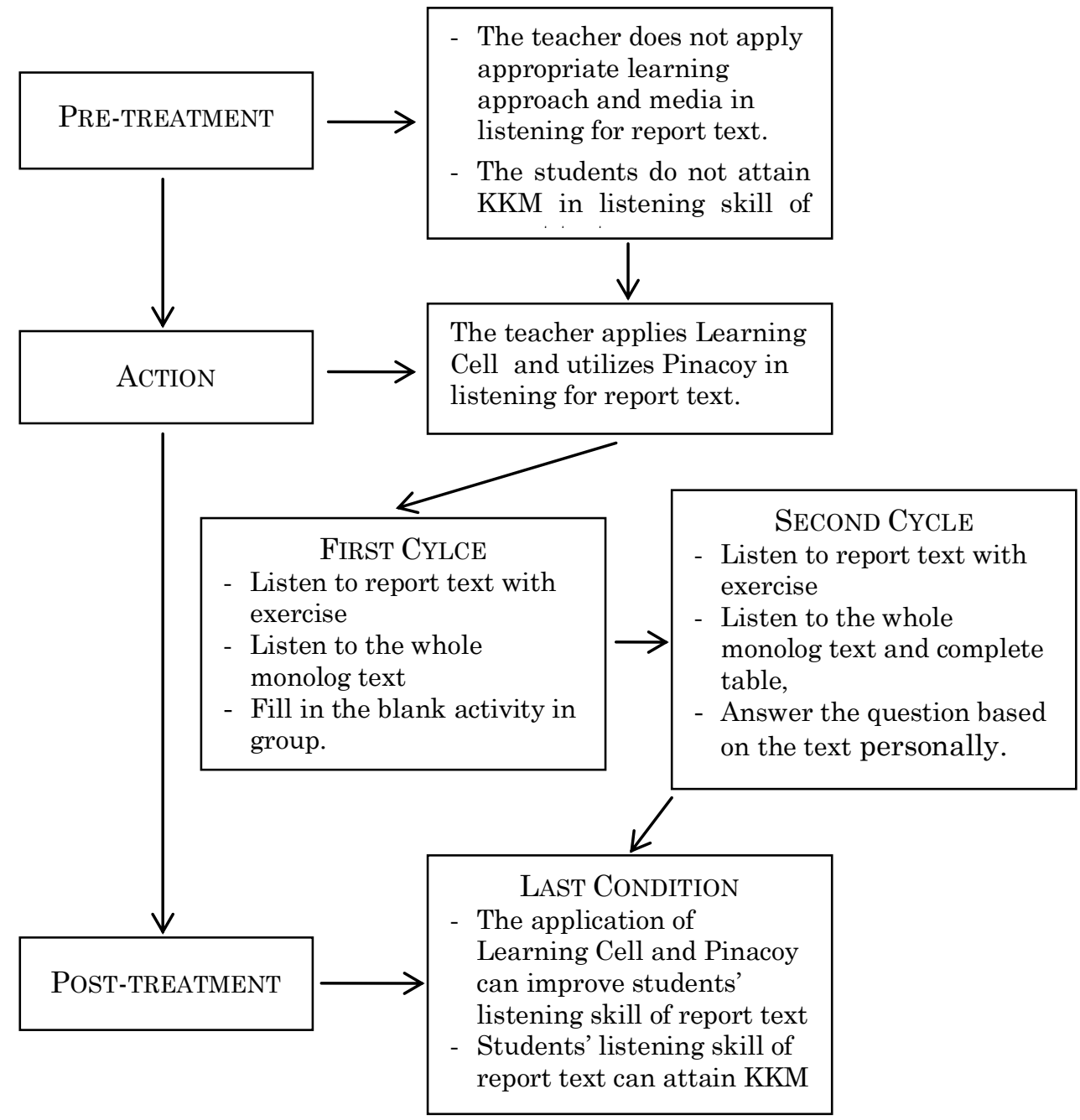

Diagram: Research Framework

data will be analyzed by comparing the results between pre-test and first cycle test, also the first cycle test and the second one.

\section{RESEARCH RESULTS}

\section{Research Implementation}

The implementation of classroom action research by applying learning cell and utilizing Pinacoy was undertaken in action cycle mechanism which consists of 4 phases, such as: planning, acting, observing, and elaboration phase- learners listen to a report text while completing several blank words in the listening script. In this phase, the teacher and learners discuss communicative purpose, generic structure, and language features of the text they listen. Subsequently, the teacher provides another text and repeats the similar learning process.

In confirmation section, the teacher gives several oral questions to the learners based on what they listen. 
More specifically, the phases of implementation are as follow.

\section{Planning}

In this section, the researcher makes plan regarding learning process in each cycle, such as constructing lesson plan with learning scenario which applies learning cell and utilizes Pinacoy, besides preparing other teaching equipments.

\section{Acting}

1. First cycle:

The teacher treats the students with basic competence learning listening report texts by applying learning cell and utilizing Pinacoy. The learning materials are a range of natural and social phenomenon presented in the form of report texts. The first cycle is conducted in at least two meetings with two teaching periods each, and one additional meeting for giving evaluation or testing in the late first cycle. In this phase, the researcher gives action or treatment applying learning cell and utilizing Pinacoy in groups. The students have less interest in considering teachers material.

2. Second cycle:

In this cycle, the learning process is almost similar to the previous one that is basic competence listening report texts implementing learning cell and utilizing Pinacoy. This second cycle is held in two meetings minimally, two learning periods each, and one supplementary meeting to conduct evaluation or test in the end of the cycle. Action done in learning process in the second cycle concerns on each student's personal activity and participation. Whereas the learning material in this cycle is a range of natural and social phenomenon texts. The students have pay attention and interest to teacher's material.
Observing

Observation in every action cycle is conducted by researcher and collaborator. In this phase, observation concerns on the learning process in the first cycle, focusing on observing the learners: (1) showing their involvement /participation in teaching-learning process. There are $68 \%$ of student at cycle 1 and there $78 \%$ of students at cycle $3 ;$ (2) recognizing sound/word spoken for instance they can identity difficult word, guess the meaning; (3) expressing opinion for example retell the report in front of class and share their idea in group discussion; (4) understanding word meaning and sentence in the text listened; and (5) completing blank text. Whereas for the teachers, the observation focuses on the teachers' skill including: (1) they motivate the learners by giving clue of the text, presenting some video related to text and giving mind mapping in the early lessonto learn; (2) the teacher also delivers materials based on recent phenomenon to attract student's interest; (3) organizes learning process by applying learning cell and utilizing Pinacoy and combine some video based on text; (4) manage the learners in class activity in small group and personally; (5) evaluate the learner's results by giving pre test and post test.

\section{Reflecting}

In this phase, the researcher with observers are doing reflection to value specialty and inadequacy of learning process in each cycle. The result of this reflection shortly becomes an instrument to determine steps in research afterward. The are some progress in students' participation at cycle 1 is $68 \%$ and cycle 2 is $75 \%$ and student's interest at cycle 1 is $72 \%$ and cycle 2 is $79 \%$.

\section{Learners' Listening Skill Observed from Evaluation Result}

Observing the evaluation result, it shows grade improvement achieved by the learners in the end of treatment in 
the first cycle and the second one. Meanwhile, the ratio of competency test results for report texts between before and after treatments both in the first and the second cycle can be seen in Chart.

\section{Learners' Listening Skill Observed} from the Performance in Learning

Based on the research data, it is revealed that compared with pretreatment condition, the learners' performance during the learning process gets enhanced in the first cycle treatment, and more improvement in the second cycle treatment. In pretreatment class, many learners had few learners still had least eagerness in learning. The quantity of learners who answered teacher's question or evaluation correctly became increased even more than in the first cycle class.

\section{Conclusion}

From this research, it can be inferred as follows:

1. The implementation of learning cell and Pinacoy influences listening skill of the eleventh grade students in class of social 2 MAN Sukoharjo in academic year 2013/2014. The result of competency test after the first and second cycles treatments proves that there are $68 \%$ students'

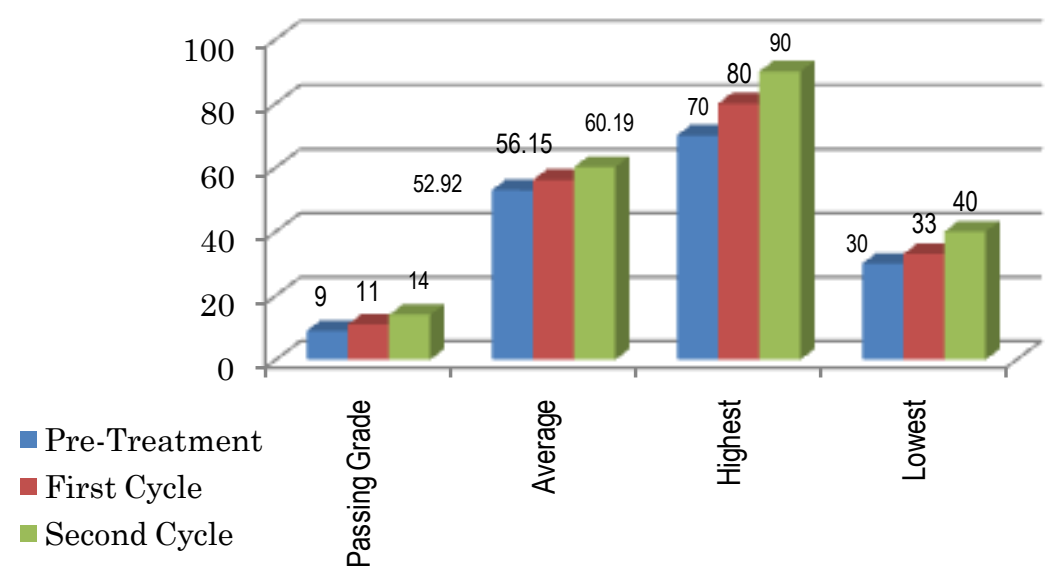

\section{Chart: The Ratio of Competency Tests}

least enthusiasm during teaching and learning process. However, most of them learned more enthusiastically than the first treatment. Further, only several learners actively participated by asking or answering teacher's questions in the first treatment.It is compared to throughout the first cycle treatment where more learners excitedly took part in class. The learners' answers and responds were mostly correct during the first cycle treatment; while in the pretreatment class, most of the time, they answered incorrectly.

During the second cycle treatment, more learners involved actively in asking and responding, while only very participation to cycle 1 and there are $75 \%$ student to cycle 2 . It also shows that there are $72 \%$ of students' interest to cycle 1 and 79 $\%$ of students's interst to cycle 2 .

2. The average score of the eleventh grade students in class of social 2 MAN Sukoharjo in academic year 2013/2014 for listening activity of report text after lerning cell and Pinacoy applied and utilized in class, could successfully achieve passing grade. It shows there are 11 students gain passing grade to cycle one and 14 students get passing grade to cycle two. 
According to the research result, it is suggested that:

1. An English teacher should be able to make use of appropriate learning media to actualize teacher professionalism and develop learning innovation in class. In addition, it is very important for an English teacher to be competent in selecting suitable learning method which properly fulfills learners' necessity in class.

2. Learners should be active and enthusiastic in participating learning process, for instance; actively inquiring or stating problems to teacher in order to find out the solution of the learning issues together. This circumstance is very essential to reach success in learning, since the excellence of material, media, and method applied by teacher will be worthless without the learners' motivation. The study can be as reference to teacher and future researcher that apply learning cell and pinacoy can make teaching learning process joyful and attract student's participation and interest in classroom.

\section{REFERENCES}

Alim, et. al. 2011. 60 Menit Mahir Mengedit dengan Pinnacle Studio untuk Pemula. Jakarta: Niaga Swadaya

Barkley et. al. 2005. Collaborative Learning Technique. Jossey-Bass. USA

Darma et. al. 2009. Buku Pintar Menguasai Internet. Jakarta: PT TransMedia.

Munadi, Yudhi. 2008. Media Pembelajaran: Sebuah Pendekatan Baru. Jakarta: Gaung Persada Press

Newton, Jonathan \& ISP Nation. 2009. Teaching ESL/EFL Listening and Speaking. London: Routledge

Song, M, 2011. "A Web Survey Program based on Computer Technology and Its Application to Evaluation Model About Youth Self-organization in China". Journal of Computer. 6 (9)

Smaldino, Sharon, DL. Lowther \& JD. Russell. 2004. Instructional Technology and Media for Learning. Ohio: Pearson.

Sujana, Nana \& Ahmad Rivai,. 2002. Media Pengajaran. Bandung: Sinar Baru Algensindo

Yunus, MM, H. Salehi, \& N. Nordin, 2011. ESL Pre-service Teacher's Perception on the Use of Paragraph Punch in Teaching Writing. Canadian Center of Science and Education 